\title{
Trends in Corporate Social Responsibility Reporting. The Case of Chinese Listed Companies
}

\author{
Xiaojuan $\mathrm{Wu}^{1,2}$ and Patrycja Hąbek ${ }^{3, * * 1}$ \\ 1 Department of Business Administration, Faculty of Economics, Technical University of Ostrava, \\ 70200 Ostrava, Czech Republic; xiaojuan.wu@vsb.cz \\ 2 Department of Accounting, School of Management, Hebei GEO University, Shijiazhuang 050031, China \\ 3 Faculty of Organization and Management, Silesian University of Technology, 41-800 Zabrze, Poland \\ * Correspondence: patrycja.habek@polsl.pl; Tel.: +48-32-277-73-71
}

Citation: Wu, X.; Hąbek, P. Trends in Corporate Social Responsibility Reporting. The Case of Chinese Listed Companies. Sustainability 2021, 13, 8640. https://doi.org/10.3390/ su13158640

\section{Academic Editors:}

Izabela Jonek-Kowalska and Lilla Knop

Received: 2 July 2021

Accepted: 30 July 2021

Published: 3 August 2021

Publisher's Note: MDPI stays neutral with regard to jurisdictional claims in published maps and institutional affiliations.

Copyright: (c) 2021 by the authors. Licensee MDPI, Basel, Switzerland. This article is an open access article distributed under the terms and conditions of the Creative Commons Attribution (CC BY) license (https:// creativecommons.org/licenses/by/ $4.0 /)$.

\begin{abstract}
Compared with Western developed countries, corporate social responsibility (CSR) implementation in China started relatively late, but so far, its development has been going on for more than ten years. Therefore, the development process of CSR reporting as a vital tool to reflect the CSR related information of Chinese listed companies is worth studying. It has been asserted in a large amount of literature that the government of a country has an important influence on the development of CSR reporting. Thus, in this paper, we aim to study the trends in CSR reporting practices of Chinese listed companies through statistical analysis methods and then consider the role of the government in it. The results show that the number of CSR reports issued by Chinese listed companies has increased year by year; notably, the number of voluntary CSR disclosure and environmental information disclosure has increased significantly. However, the overall disclosure rate of CSR reports is low and shows no upward trend, the published CSR reports lack third-party certification, and the information disclosure level of most CSR reports is concentrated at a relatively low level. The findings provide some useful references for the future development of Chinese CSR related laws, regulations, and guidelines.
\end{abstract}

Keywords: CSR report; Chinese listed companies; environmental information; government role; voluntary disclosure; regulations

\section{Introduction}

As the concept and practice of corporate social responsibility (CSR) have attracted more and more attention [1,2], CSR reporting as the tool of communicating CSR information has naturally become one of the foci of academics [3-8]. Many Western developed countries have required their companies to release CSR-related information since 2000. For example, all listed companies in France must disclose information about social and environmental conditions in their annual reports since 2001 [9]. Danish companies are required to report their sustainability performance as of 2001 [10]. Compared with developed countries, it is relatively late for China to require companies to compulsorily disclose CSR-related information. The earliest requirement for mandatory disclosure of CSR reports was issued in 2008. So far, CSR reporting in China has also experienced more than ten years of development; thus, the evolution of these practices is a topic worthy of study. In addition, the government of a country has played an important role in the development of CSR reporting [11-13]. Therefore, the aim of this paper is to analyze the trends in CSR reporting of Chinese listed companies as well as indicating the government's role in development of CSR reporting practices in China.

With this study, we make three contributions to the literature. First, in this study, we provide a comprehensive analysis of the trends in CSR reporting of Chinese listed companies. The analysis coverage comprises all Chinese listed companies and the most recent 12 years since China's first mandatory CSR reporting requirement emerged. Second, 
in this study, we summarize China's CSR-related laws, regulations, and guidelines from 2006 to 2018 in chronological order, which is beneficial to the English-speaking academia to update their understanding of China's CSR reporting requirements and guidelines. Third, we explore the role of the government in the development of CSR reporting of Chinese listed companies by comparing the law, regulation, and guidelines on CSR issues in China with the trend of CSR reporting. Our findings provide the Chinese government with insight into CSR reporting and indicate the need to further strengthen the supervision of CSR disclosures.

Reporting of CSR can generally be seen as the practice of an organization to provide its stakeholders with information about its economic, environmental, and social aspects [14-16]. Due to differences in the understanding of CSR and the focus of the report, many terms are often used simultaneously in the literature and business practices: CSR report, sustainability report, corporate citizenship report, and nonfinancial reports. In this paper, these terms are treated interchangeably. The rest of the paper is structured as follows. In the next section, we provide an overview of CSR reporting in China, with a particular emphasis on CSR-related laws, regulations, and guidelines. This is followed by a section dedicated to methodology used in the research process. We then present the research findings concerning the number, type of CSR disclosures, its verification, and degree of disclosure, taking environmental information disclosure into account. The paper ends with a discussion section and conclusions including limitations as well as recommendations for further research.

\section{Literature Review}

In the past few decades, many scholars and institutions around the world have paid attention to CSR reporting. Klynveld Peat Marwick Goerdeler (KPMG) studies the development trend of sustainability reports from a global perspective and published the first edition of the KPMG Survey of Sustainability Reporting in 1993. The latest edition of the KPMG Survey of Sustainability Reporting 2020 [17] takes as a sample the top 100 companies by revenue in each of 52 countries (N 100) and the 250 largest companies in the world defined in the Fortune 500 ranking in 2019 (G 250). Its results show that 80 percent of N100 companies worldwide now report on sustainability; North America has the highest sustainability reporting rate $(90 \%)$; approximately two-thirds $(65 \%)$ of companies reporting globally have set targets to reduce carbon emissions; more than twothirds $(69 \%)$ of reporting companies have linked their business activities with the United Nations Sustainable Development Goals (SDGs), and so on. Ali, Frynas, and Mahmood found that CSR reports in developing and developed countries are driven by different determinants based on a recent analysis of CSR literature [18]. Bondi and Yu conducted a cross-cultural analysis of Chinese, Italian, and American CSR reports [19]. Some scholars prefer to study CSR reports of specific industries on a global scale, such as the airline industry [20], the fashion industry [21], and the automotive industry [22].

Many scholars and institutions have conducted specific research on CSR reporting in China from different perspectives. These studies are mainly divided into two categories. The first kind of research focuses on the relationship between CSR reporting and company characteristics, such as the relationship between ESG reporting or CSR practice and financial performance $[23,24]$, the association between voluntary CSR reporting and financial statement auditing [25], the heterogeneous links between board gender diversity and corporate social performance [26], the effect of the internal side of social responsibility on the firm competitive success [27], how the assurance of sustainability reports affect stock market price [28], etc. The second kind of research focuses on CSR reporting, e.g., the analysis on the content of China's sustainability report [29], a summary of the requirements of the CSR reporting in China [12], and identifying whether the CSR reports are symbolic or substantive [30], exploring of the main drivers of CSR and CSR reporting of large Chinese listed companies [31], comparing of the form and content of CSR reports between Chinese multinational corporations and their Western counterparts [32], evaluating the quality 
of CSR reports through a comparative analysis of Chinese state-owned and private real estate companies [33], and so on. In the second study, an interesting phenomenon can be found, that is, the figure of government can be seen frequently. For example, how the risk of governmental monitoring affects the extent to which CSR reports are symbolic or substantive [30], whether institutional pressure is a key driving factor in shaping CSR and its reporting [31], how companies respond to CSR reports in the face of conflicting requirements from the central government and local governments [34], how the Chinese government prioritized sustainable development issues [35], and many more. This phenomenon confirms the conclusion that the government of a country has indeed played an essential role in the development of CSR reporting [11-13]. In summary, the existing papers on CSR reporting are either based on the overall situation but earlier in time $[12,29]$ or based on a relatively short time [23,30,34] or a specific subject or industry [31-33]. The aim of this study is to fill this gap of exploring the overall trend of CSR reporting of Chinese listed companies from 2008, when the first mandatory requirement for CSR reporting emerged in China, to the present.

\subsection{Overview of CSR Laws, Regulations, and Guidelines in China}

If a country's market cannot provide companies with sufficient incentives to voluntarily report their social and environmental impacts, the local government can legally require reporting through the company law, stock listing regulations or mandatory disclosure laws [12]. Table 1 pools China's laws, regulations, and guidelines related to CSR from 2006 to 2018 in chronological order.

Table 1. Summary of key mandatory and voluntary law, regulation, and guidelines on CSR issues in China.

\begin{tabular}{|c|c|c|c|c|}
\hline Year & Name & Issuer & Content Description & $\mathbf{M} / \mathrm{V}^{1}$ \\
\hline 2006 & $\begin{array}{l}\text { Company Law of the } \\
\text { People's Republic of } \\
\text { China [36] }\end{array}$ & Chinese government & $\begin{array}{l}\text { Article 5-requires companies to comply with } \\
\text { social morality and bear social responsibilities } \\
\text { Article } 17 \text {-requires companies to protect the } \\
\text { lawful rights and interests of its employees }\end{array}$ & M \\
\hline 2006 & $\begin{array}{l}\text { Shenzhen Stock } \\
\text { Exchange Social } \\
\text { Responsibility } \\
\text { Instructions to Listed } \\
\text { Companies [37] }\end{array}$ & $\begin{array}{l}\text { Shenzhen Stock } \\
\text { Exchange } \\
\text { (SZSE) }\end{array}$ & $\begin{array}{l}\text { Encourage listed companies to establish social } \\
\text { responsibility mechanism and prepare social } \\
\text { responsibility reports on a regular basis }\end{array}$ & $\mathrm{V}$ \\
\hline 2008 & $\begin{array}{c}\text { Guidelines for } \\
\text { Environmental } \\
\text { Information Disclosure } \\
\text { of Companies Listed on } \\
\text { the Shanghai Stock } \\
\text { Exchange [38] }\end{array}$ & $\begin{array}{l}\text { Shanghai Stock } \\
\text { Exchange (SSE) }\end{array}$ & $\begin{array}{l}\text { Require companies to disclose environmental } \\
\text { information and CSR strategy in format either } \\
\text { part of CSR report or separate report } \\
\text { (For companies that value social responsibility } \\
\text { and can actively disclose social responsibility } \\
\text { reports, the Exchange will give priority to their } \\
\text { selection in the corporate governance section of } \\
\text { the SSE and simplify the review of their } \\
\text { temporary announcements accordingly) }\end{array}$ & M \\
\hline 2008 & $\begin{array}{l}\text { Notification on the } \\
\text { Issuance of the } \\
\text { Guideline on Fulfilling } \\
\text { Social Responsibility by } \\
\text { Central Enterprises [39] }\end{array}$ & $\begin{array}{l}\text { The State-owned } \\
\text { Assets Supervision and } \\
\text { Administration } \\
\text { Commission of the } \\
\text { State Council }\end{array}$ & $\begin{array}{l}\text { Require companies to establish CSR fulfillment } \\
\text { mechanisms and CSR information reporting } \\
\text { systems for central state-owned enterprises }\end{array}$ & M \\
\hline 2008 & $\begin{array}{l}\text { Notice for better } \\
\text { preparing the } 2008 \\
\text { Annual Reports of } \\
\text { Listed Companies [40] }\end{array}$ & SSE & $\begin{array}{l}\text { Companies belonging to any of these three types } \\
\text { must prepare CSR report: listed on the SSE } \\
\text { Corporate Governance Section; issue foreign } \\
\text { capital stocks listed abroad; listed companies in } \\
\text { financial sectors. }\end{array}$ & M \\
\hline
\end{tabular}


Table 1. Cont.

\begin{tabular}{|c|c|c|c|c|}
\hline Year & Name & Issuer & Content Description & $\mathbf{M} / \mathbf{V}^{1}$ \\
\hline 2008 & $\begin{array}{c}\text { Notice for better } \\
\text { preparing the } 2008 \\
\text { Annual Reports of } \\
\text { Listed Companies [41] }\end{array}$ & SZSE & $\begin{array}{l}\text { The companies belonging to SZSE } 100 \text { index } \\
\text { constituent stocks should prepare CSR report } \\
\text { along with annual report; encourage other listed } \\
\text { companies voluntarily disclose CSR report. } \\
\text { (later, the main board and Small and Medium } \\
\text { Enterprise (SME) Board in } 2015 \text { and Growth } \\
\text { Enterprises Market (GEM) Board in } 2016 \\
\text { incorporated this notice into the “Information } \\
\text { Disclosure Business Memorandum" for the } \\
\text { disclosure of related matters in regular reports) }\end{array}$ & $\mathrm{M}$ and $\mathrm{V}$ \\
\hline 2009 & $\begin{array}{l}\text { China CSR Reporting } \\
\text { Guidelines } \\
\text { (CASS-CSR1.0) [42] }\end{array}$ & $\begin{array}{l}\text { The CSR Research } \\
\text { Center of the Chinese } \\
\text { Academy of Social } \\
\text { Sciences (CASS)) }\end{array}$ & $\begin{array}{l}\text { Provide instructions and performance indicators } \\
\text { to guide different industries to report CSR issues } \\
\text { in China. } \\
\text { (In 2017, the fourth edition of the guidelines } \\
\text { CASS-CSR } 4.0 \text { [43] was released) }\end{array}$ & $\mathrm{V}$ \\
\hline 2015 & $\begin{array}{c}\text { Environmental } \\
\text { Protection Law [44] }\end{array}$ & $\begin{array}{c}\text { Chinese government- } \\
\text { Standing Committee of } \\
\text { the National People's } \\
\text { Congress }\end{array}$ & $\begin{array}{l}\text { Article 55-requires organizations that discharge } \\
\text { key pollutants should truthfully disclose the } \\
\text { following information to the public: the name of } \\
\text { the main pollutant; the method of discharge; the } \\
\text { concentration and total amount of discharge, the } \\
\text { situation of excessive discharge, the construction } \\
\text { and operation of pollution prevention facilities }\end{array}$ & M \\
\hline 2016 & $\begin{array}{l}\text { The Standards } \\
\text { Concerning the } \\
\text { Contents and Formats } \\
\text { of Information } \\
\text { Disclosure by } \\
\text { Companies Offering } \\
\text { Securities to the Public } \\
\text { No.2-Contents and } \\
\text { Formats of Annual } \\
\text { Reports [45] }\end{array}$ & $\begin{array}{c}\text { China Securities } \\
\text { Regulatory } \\
\text { Commission }\end{array}$ & $\begin{array}{l}\text { Require companies and their subsidiaries that are } \\
\text { key pollutant discharge organizations announced } \\
\text { by the environmental protection department to } \\
\text { disclose relevant environmental information. } \\
\text { (In the } 2017 \text { revision, require companies other } \\
\text { than key pollutant discharge organizations to } \\
\text { disclose their environmental information } \\
\text { according to the requirements. If they do not } \\
\text { disclose, explain the reasons appropriately; } \\
\text { encourage companies to voluntarily disclose } \\
\text { relevant information that is conducive to } \\
\text { protecting the ecology, preventing pollution, and } \\
\text { fulfilling environmental responsibilities) }\end{array}$ & $\mathrm{M}$ and $\mathrm{V}$ \\
\hline 2016 & $\begin{array}{l}\text { Guidelines for } \\
\text { Establishing the Green } \\
\text { Financial System [46] }\end{array}$ & $\begin{array}{l}\text { The People's Bank of } \\
\text { China, The Ministry of } \\
\text { Finance, National } \\
\text { Development and } \\
\text { Reform Commission, } \\
\text { The Ministry of } \\
\text { Environment } \\
\text { Protection, China } \\
\text { Banking Regulatory } \\
\text { Commission, } \\
\text { China Securities } \\
\text { Regulatory } \\
\text { Commission, China } \\
\text { Insurance Regulatory } \\
\text { Commission }\end{array}$ & $\begin{array}{l}\text { Vigorously develop green lending, e.g., establish } \\
\text { a policy framework to support green lending, } \\
\text { and promote securitization of green loans, etc.; } \\
\text { enhance the role of the Securities Market in } \\
\text { supporting green investment, e.g., actively } \\
\text { support the qualified green enterprises to obtain } \\
\text { financing via initial public offerings and } \\
\text { secondary offerings, and gradually establish and } \\
\text { improve the mandatory environmental } \\
\text { information disclosure system for listed } \\
\text { enterprises and bond issuers, etc. } \\
\text { Since 2017, listed companies listed on the list of } \\
\text { key emission companies by the Ministry of } \\
\text { Environmental Protection have mandatory } \\
\text { disclosure of environmental information; in 2018, } \\
\text { if companies do not disclose environmental } \\
\text { information, they must explain why; by 2020, all } \\
\text { listed companies are required to compulsorily } \\
\text { disclose environmental information. }\end{array}$ & M \\
\hline
\end{tabular}


Table 1. Cont.

\begin{tabular}{|c|c|c|c|c|}
\hline Year & Name & Issuer & Content Description & $\mathbf{M} / \mathbf{V}^{1}$ \\
\hline 2017 & $\begin{array}{l}\text { Provisions on the } \\
\text { Management of the List } \\
\text { of Organizations } \\
\text { Discharging Key } \\
\text { Pollutants [47] }\end{array}$ & $\begin{array}{l}\text { Ministry of Ecology } \\
\text { and Environment }\end{array}$ & $\begin{array}{l}\text { According to environmental factors such as water, } \\
\text { atmosphere, soil, sound, etc., implement } \\
\text { classified management on the list of } \\
\text { organizations discharging key pollutants. } \\
\text { (The local government determines the list of } \\
\text { organizations discharging key pollutants in the } \\
\text { administrative region) }\end{array}$ & M \\
\hline 2018 & $\begin{array}{l}\text { Code of Corporate } \\
\text { Governance for Listed } \\
\text { Companies [48] }\end{array}$ & $\begin{array}{c}\text { China Securities } \\
\text { Regulatory } \\
\text { Commission }\end{array}$ & $\begin{array}{l}\text { Article 86-A listed company should actively } \\
\text { implement the concept of green development, } \\
\text { integrate ecological and environmental protection } \\
\text { requirements into the development strategy and } \\
\text { corporate governance process, actively } \\
\text { participate in the construction of ecological } \\
\text { civilization, and play an exemplary role in } \\
\text { pollution prevention, resource conservation, and } \\
\text { ecological protection. }\end{array}$ & V \\
\hline
\end{tabular}

Note: ${ }^{1}$. M represents mandatory disclosure and V represents voluntary disclosure. Source: based on [12].

\subsection{Characteristics of CSR Laws, Regulations and Guidelines in China}

According to the contents of Table 1, we further analyzed and identified two characteristics of these CSR-related laws, regulations and guidelines during the evolution process: (a) coexistence of voluntary and mandatory disclosure requirements for CSR reports, and (b) emphasis on environmental information disclosure.

\subsubsection{Coexistence of Voluntary and Mandatory Disclosure Requirements for CSR Reports}

The Shenzhen Stock Exchange (SZSE) was the earliest to encourage its listed companies to voluntarily publish CSR reports. The SZSE Social Responsibility Instructions to Listed Companies were released in September 2006 with the aim of encouraging listed companies to publish CSR reports along with their annual reports. The mandatory disclosure requirements for CSR reports emerged in 2008. According to article 11 of Notice for Better Preparing 2008 Annual Reports, the companies listed in the Shenzhen 100 Index should disclose CSR reports and, at the same time, small and medium listed enterprises are encouraged to issue CSR reports. In 2008, Shanghai Stock Exchange (SSE) also issued a Notice for Better Preparing 2008 Annual Reports of Listed Companies, requiring three types of companies to disclose the CSR reports at the same time as their annual reports and encourage other companies to do the same. The three types of mandatory disclosure companies are ones listed on the SSE Corporate Governance Section, issuing foreign capital stocks listed abroad, and listed companies in financial sectors. In addition, the State-owned Assets Supervision and Administration Commission of the State Council published a Notification on the Issuance of the Guideline on Fulfilling Social Responsibility by Central Enterprises in the same year. The central state-owned enterprises are required to establish a CSR fulfillment mechanisms and CSR information reporting systems. Thus, since 2008, the requirement for mandatory and voluntary disclosure of CSR report have coexisted in China.

\subsubsection{Emphasis on Environmental Information Disclosure}

To address increasing environmental problems, the SSE released Guidelines for Environmental Information Disclosure of Companies Listed on the SSE in 2008. For the first time, clear requirements were put forward for listed companies in terms of environmental information disclosure, especially for companies engaged in industries that have a greater impact on the environment, such as thermal power generation, steel, cement, electrolytic aluminum, and mineral mining as well as listed companies included in the list of severely polluting companies of the environmental protection department. In 2015, Environmental 
Protection Law was promulgated by the Chinese government. It is in the form of law to enhance the obligation of companies to disclose environmental information. One year later, the China Securities Regulatory Commission released the revised Standards Concerning the Contents and Formats of Information Disclosure by Companies Offering Securities to the Public No. 2-Contents and Formats of Annual Reports. It emphasized the content of environmental information that should be disclosed in the annual report and stimulated companies to voluntarily disclose relevant information that is conducive to protecting ecosystems, preventing pollution, and fulfilling environmental responsibilities. In the same year, Guidelines for Establishing the Green Financial System was issued. Green finance refers to provide preferential and priority financial services for the investment, financing, operations, risk management of projects in the fields of environmental protection, energy conservation, clean energy, green transportation, and green buildings. It shows that China's policy on CSR issues has entered the incentive stage [49], which is to provide attractive financial support to the companies engaging in and disclosing the green projects. In the next year, Provisions on the Management of the List of Organizations Discharging Key Pollutants were issued by the Ministry of Ecology and Environment. These regulations implement classified management on the list of organizations that discharge key pollutants based on environmental factors such as water, atmosphere, soil, sound, etc. In 2018, the Code of Corporate Governance for Listed Companies was revised and required listed companies to actively implement the concept of green development, integrate ecological and environmental protection requirements into the development strategy and corporate governance process, actively participate in the construction of ecological civilization, and play an exemplary role in pollution prevention, resource conservation, and ecological protection. From the evolution of these laws, regulations, and guidelines related to environmental information disclosure, it can be seen that the Chinese government and regulatory agencies pay more and more attention to the disclosure of the environmental aspect of CSR.

\section{Methodology of Research}

\subsection{Research Process and Method Used}

In order to achieve the research purpose of this paper, three stages are carried out. First, we screen the laws, regulations, and guidelines related to CSR reporting and list their evolution in chronological order. Next, the statistical analysis, including trend analysis and cross-section analysis, is adopted to research the trends in CSR reporting of Chinese listed companies. Finally, the strength and weakness of CSR reporting of Chinese listed companies are summarized based on the analysis in the previous stage, and through a comparative analysis of the laws, regulations, and guidelines related to CSR, the role of the Chinese government in the CSR reporting trends is indicated.

\subsection{Sample of Research and Source of Data}

This research takes as a sample the CSR reports disclosed by A-share (these stocks are subscribed and traded in renminbi, which distinguishes from B-share subscribed and traded in foreign currencies) companies listed on mainland China (hereinafter referred to as Chinese listed companies) from 2008 to 2019. All data come from the China Security Market and Accounting Research (CSMAR) database [50] and the evaluation reports published by Rankins CSR Ratings (RKS) agency [51]. CSMAR and RKS have different emphasis on the collection of CSR report information, but they have some common points in the basic information of CSR report. In this paper, these two data sources must sometimes be used at the same time for several objective reasons. The first reason is the accuracy of the data. As one of the earliest professional CSR rating agencies in China, RKS began to evaluate all CSR reports disclosed by Chinese listed companies in 2008, whereas CSMAR started collecting information related to CSR reports relatively late and its early CSR data were collected retrospectively. Thus, in terms of the accuracy of the early data, RKS is better than CSMAR. The second reason is the availability of data. Because, since 2018, the RKS has shifted to assessing the environmental, social, and governance (ESG) aspects of Chinese 
listed companies included in the China Securities Index 800 (CSI 800), the object, content, and standards of the assessment have undergone great changes. In order to maintain the comparability of the relevant data of the CSR reporting of Chinese listed companies, the data from RKS are as of 2017, which were released in 2018. To sum up, so as to use as accurate and available data as possible to research the historical overview of CSR reporting of Chinese listed companies, both RKS and CSMAR data are used when necessary, that is, part of the data available from RKS from 2008 to 2017, and the rest comes from CSMAR.

\section{Results}

\subsection{Overall Analysis of CSR Reporting of Chinese Listed Companies}

The results of analysis allow us to observe that in the past 12 years, the number of CSR reports issued by Chinese listed companies has shown an increasing trend (see Figure 1). However, as the total number of Chinese listed companies has increased year by year, except for 2008, the disclosure rate of CSR reports (as shown by the orange line in Figure 1, which is equal to the number of CSR reports issued by Chinese listed companies each year divided by the total number of Chinese listed companies that year) every year has basically remained between $24 \%$ and $28 \%$. The result indicates that CSR reporting of Chinese listed companies is still at a low level.

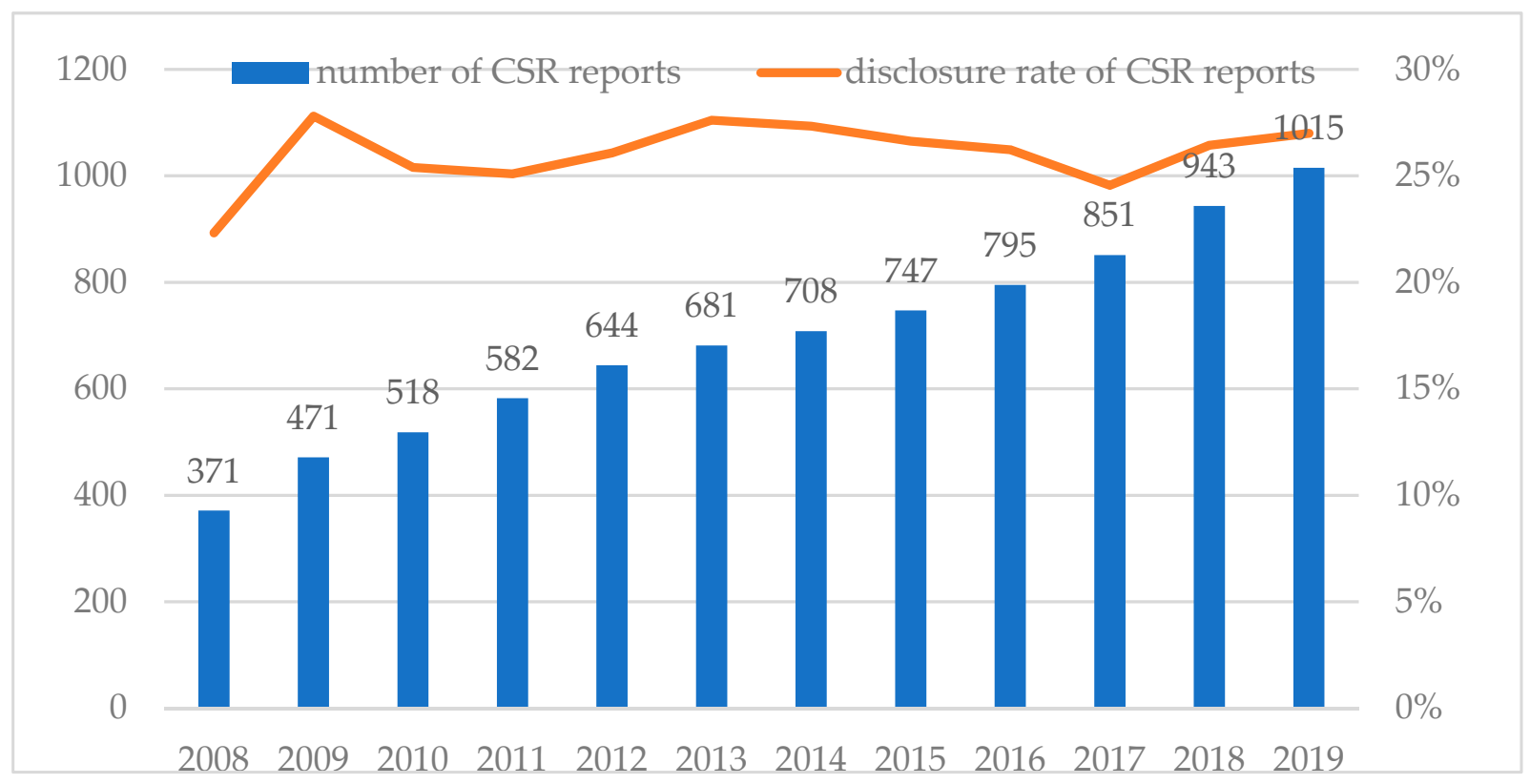

Figure 1. Number and disclosure rate of CSR reports published by Chinese listed companies. Source: Data for 2008-2017 RKS database, data for 2018 and 2019 CSMAR database.

Aside from the knowledge of the overall trend in CSR reporting of Chinese listed companies, it was interesting to determine the portion of the published reports that resulted from introducing mandatory CSR reporting regulations in China. The results of analysis revealed that the number of voluntarily disclosed CSR reports in 2010 was only 145, which is less than half of the number of the CSR reports that were mandatorily disclosed. However, the number of voluntarily disclosed CSR reports in 2017 exceeded the number of mandatorily disclosed CSR reports for the first time, and this trend continued in 2018 and 2019 (see Figure 2). The results may indicate that more and more Chinese listed companies are aware of the importance of CSR reports and are therefore willing to voluntarily disclose CSR reports. 


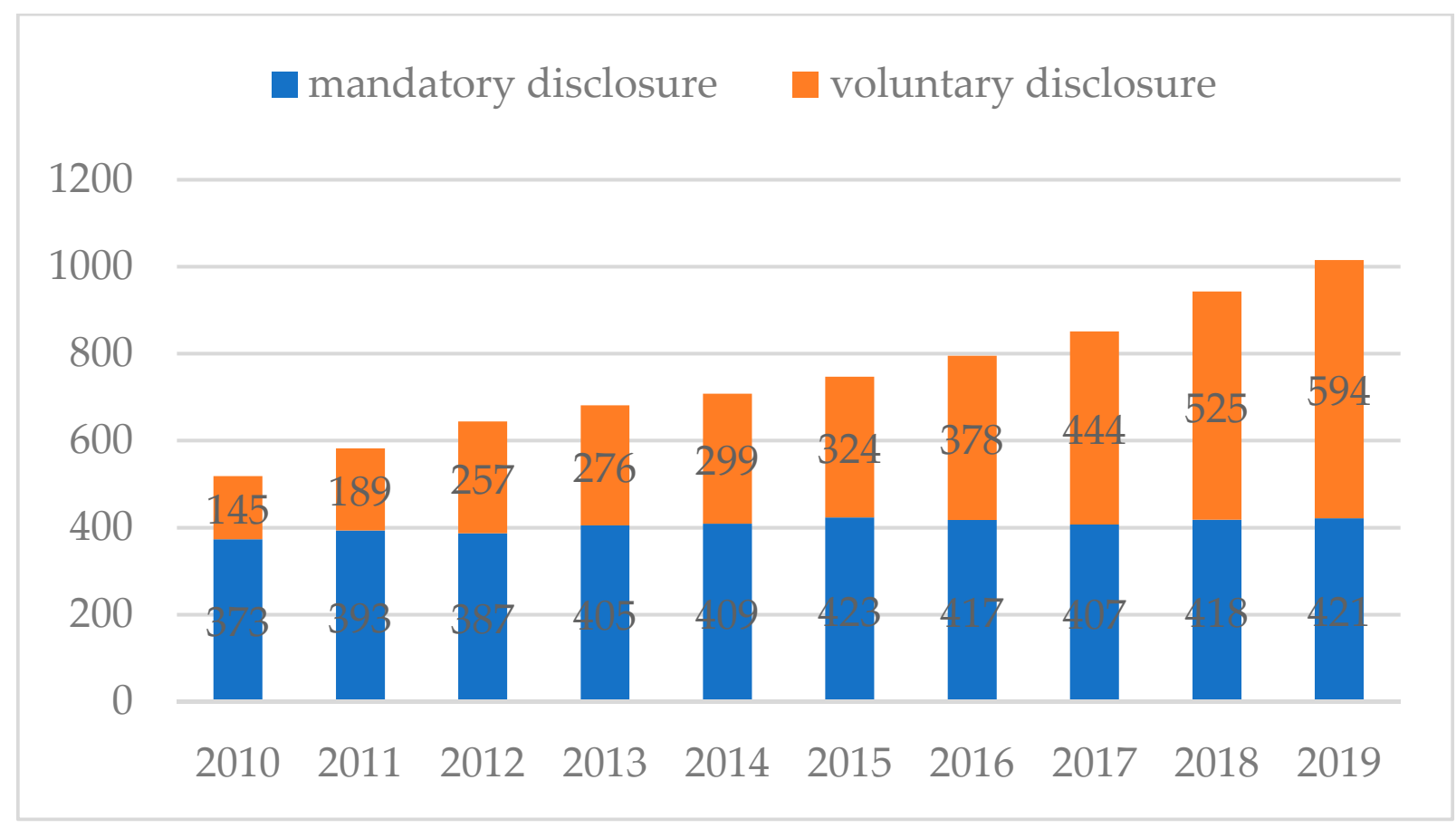

Figure 2. Number of mandatory and voluntary CSR reports of Chinese listed companies. Source: Data for 2010-2017 RKS database, data for 2018 and 2019 CSMAR database.

The analysis of the distribution of CSR reports among industry sectors showed that the industry that discloses the most CSR reports among Chinese listed companies in 2019 is the manufacturing industry (see Figure 3). The financial industry follows closely behind with 93 CSR reports. The next four industries only have more than 50 CSR reports. In the tenth-largest industry, only 25 CSR reports have been released. At the same time, it can be seen that in terms of the total disclosure rate of CSR reports in each industry (as shown by the grey line in Figure 3, which is equal to the total number of CSR reports issued by each industry divided by the total number of Chinese listed companies in the corresponding industry), the financial industry ranks first, reaching $85.32 \%$, while the information transmission, software, and information technology service industry ranks last with only $19.13 \%$. In addition, among disclosed CSR reports, the voluntary disclosure rate of CSR reports (as shown by the orange line in Figure 3, which is equal to the number of CSR reports voluntarily issued by each industry divided by the total number of CSR reports in the corresponding industry) in the financial industry is the lowest, at $0 \%$, while in other industries, the rate remains within the range of $45-75 \%$.

As external, third-party verification of the CSR report is a favorable guarantee of its credibility, the crucial issue was to check the rate of externally verified CSR reports of Chinese listed companies, which were published within the analyzed time span. The findings showed that only 35 CSR reports published in 2017 were externally verified, reaching a peak, and then gradually decreasing (see Figure 4). 


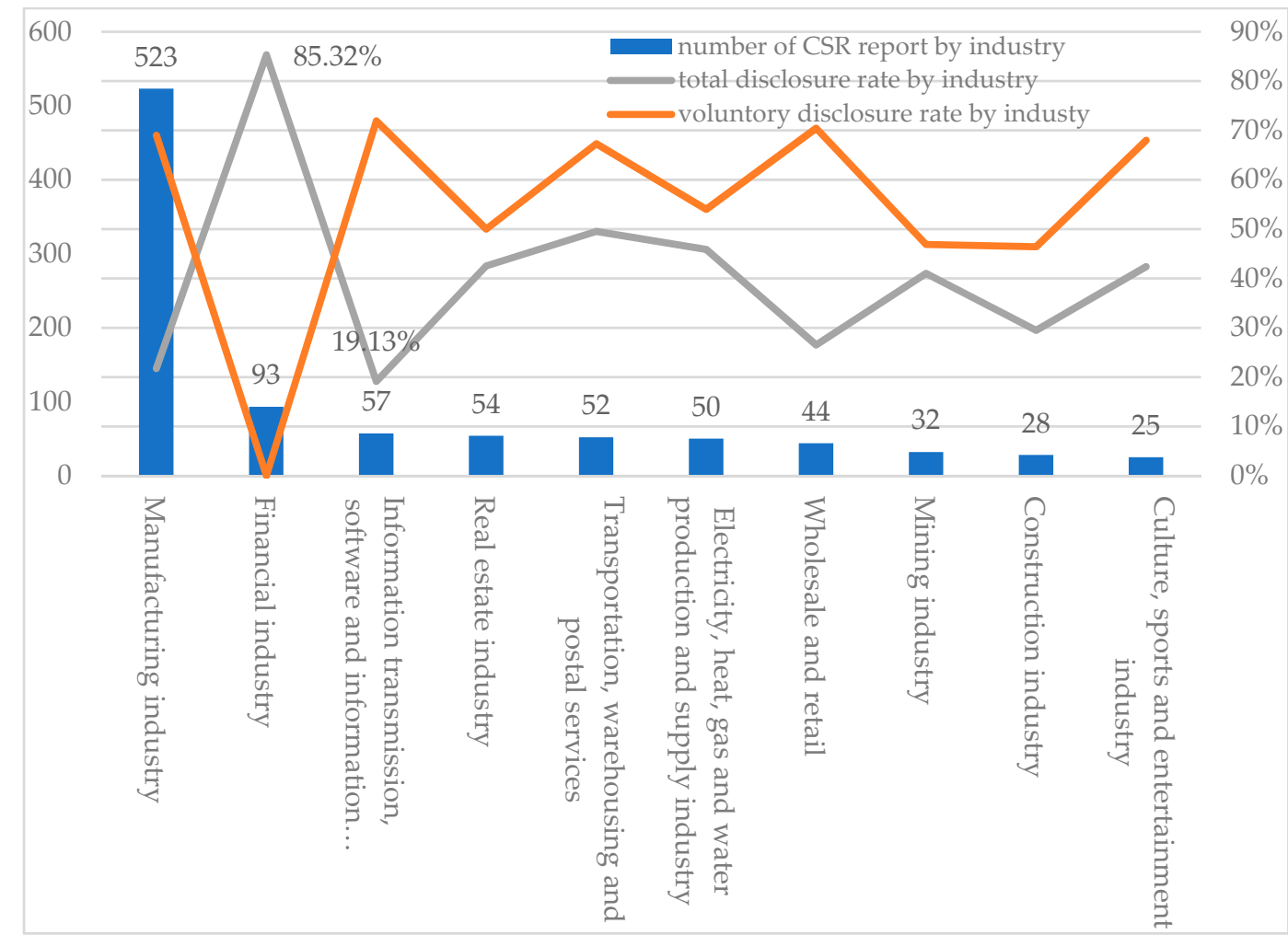

Figure 3. Statistics of China's top ten industries with the largest number of CSR reports in 2019. Source: CSMAR database.

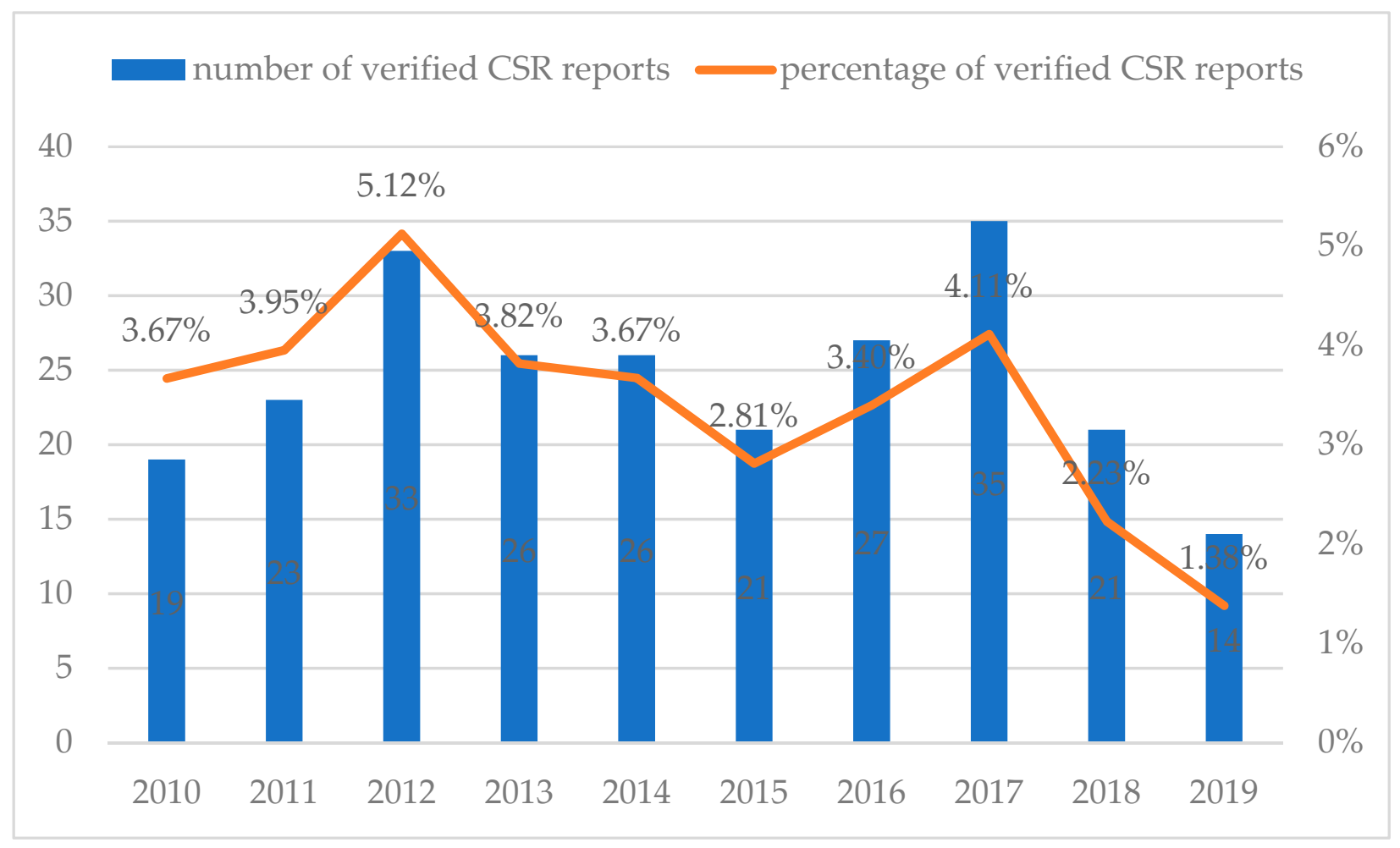

Figure 4. Number and percentage of verified CSR reports of Chinese listed companies. Source: CSMAR database. 


\subsection{Disclosure Degree of CSR Report}

Rankins CSR Ratings (RKS) is an authoritative third-party CSR rating agency in China (not related to the Chinese government) dedicated to providing objective and scientific CSR rating information for socially responsible investors (SRI), responsible consumers, and the general public. It conducts professional work in three major areas: CSR report ratings of Chinese listed companies, ESG sustainability ratings of Chinese listed companies, and SRI services. RKS evaluates CSR reports of Chinese listed companies mainly on the basis of information and data disclosed by Chinese listed companies as well as by other authoritative websites. They will announce the evaluation results at the end of each year. Chinese listed companies are evaluated for free, but if they want to know detailed evaluation information, they need to pay. With reference to the Global Reporting Initiative (GRI) G3 Guide, Sustainability Report Evaluation Guide and ISO 26000, RKS independently developed a CSR report rating system for Chinese listed companies, which includes four level-1 indicators: macrocosm (M), content (C), technical (T), and industry (I). Among them, the level-2 subindicators of the macrocosm-level indicator $\mathrm{M}$ were designed based on the overall information related to CSR, including strategy, governance, and stakeholders, e.g., social responsibility goal setting and achievement information, social responsibility management department information, stakeholder definition and identification information, etc. The level-2 subindicators of the content-level indicator $\mathrm{C}$ were designed based on the perspective of CSR-related content, including economic performance, labor and human rights, the environment, fair operation, consumers, and community engagement, and development. The level-2 subindicators of the technicallevel indicator T were designed from the perspective of CSR information expression and transmission, such as content balance, credibility and transparency, and the availability and effectiveness of information delivery, etc. This evaluation system rates CSR reports using the expert grading method, and the total score is 100 . For the setting of specific indicators, scoring standards and weight distribution, see [52]. Therefore, the evaluation results of the CSR report released by RKS reflect the degree of CSR information disclosure in the CSR report of Chinese listed companies.

To analyze the level of disclosure of information in the CSR reports of Chinese listed companies we divided the disclosure degree into four levels based on their evaluation scores published by RKS (see Table 2).

Table 2. Classification of disclosure degree of CSR report of Chinese listed companies.

\begin{tabular}{cc}
\hline Disclosure Degree & Evaluation Score \\
\hline High & $75-100$ \\
Average & $50-75$ \\
Low & $25-50$ \\
Very low & $0-25$ \\
\hline
\end{tabular}

Beginning from 2009 to 2017, the number of CSR reports at all levels except the very low level increased (see Figure 5). Secondly, the number of CSR reports with a high degree of disclosure is always small, and CSR reports with an average degree of disclosure are not the main body while most CSR reports are at a low disclosure level. 


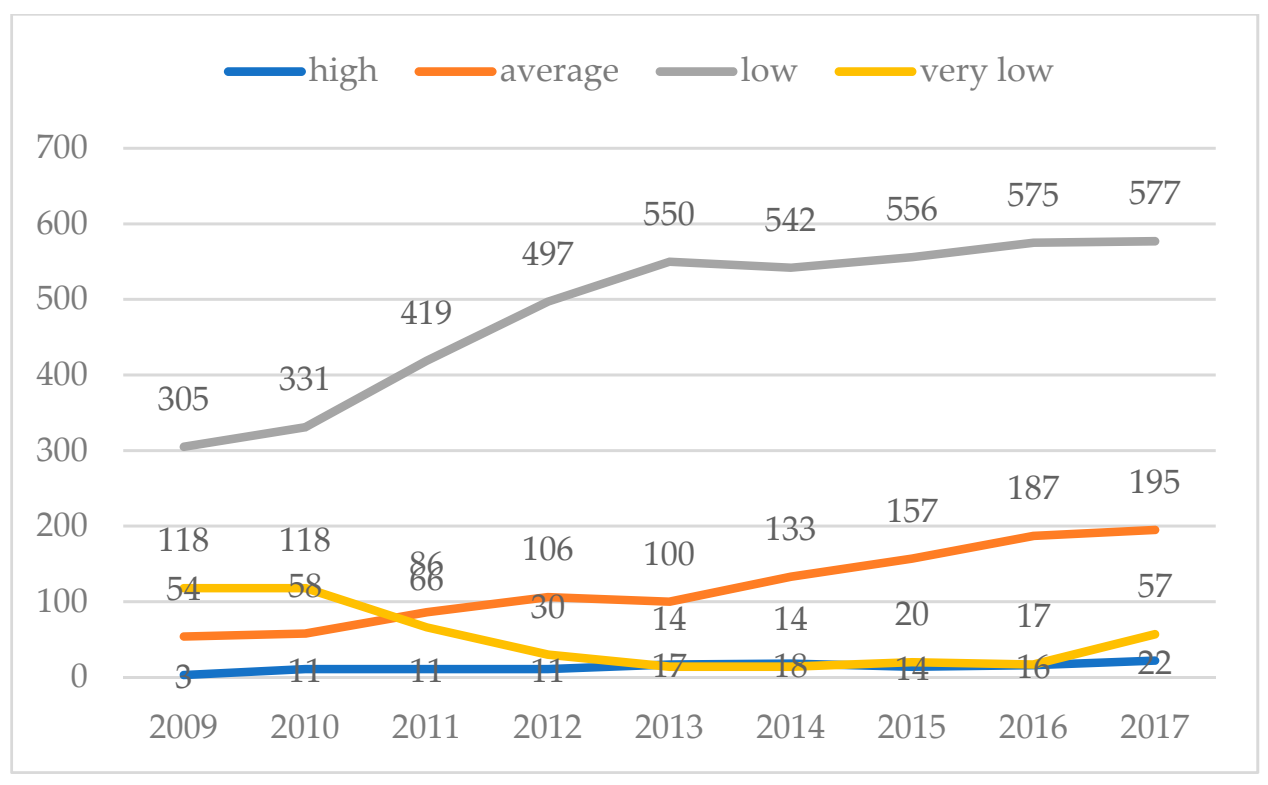

Figure 5. Statistics on the disclosure degree of CSR reports of Chinese listed companies. Source: RKS database.

\subsection{Analysis of Environmental Information Disclosure}

The impact of company business operation on the environment is one of three themes of CSR. China's economy has made great achievements, but environmental pollution has become a serious problem that must be faced [53]. It not only affects the human settlement environment but also restricts future economic development [54]. The Chinese listed companies are the outstanding representatives of Chinese companies and the backbone of China's economy. Therefore, how much they attach importance to the environmental impact of business activities reflect the development tone of the Chinese environmental issue. It is necessary to specifically analyze the trend of environmental information disclosure by Chinese listed companies. Figure 6 shows the number of Chinese listed companies that disclosed environmental information in their annual reports, CSR reports, or environmental reports from 2014 to 2019. It can be seen that more and more companies disclose their environmental information in their annual reports, and even a small number of companies have issued environmental reports specifically. The total disclosure rate of environmental information (the rate of the sum of the number of listed companies that disclosed environmental information in any report divided by the total number of listed companies that year), as shown by the yellow line in Figure 6, increased from $71.44 \%$ in 2015 to $94.91 \%$ in 2017, and remained at around 94\% in the following two years. Such a high rate of environmental information disclosure indicates that most Chinese listed companies are passively or actively considering how their business activities affect the environment, which is a positive signal to improve the environmental situation. 


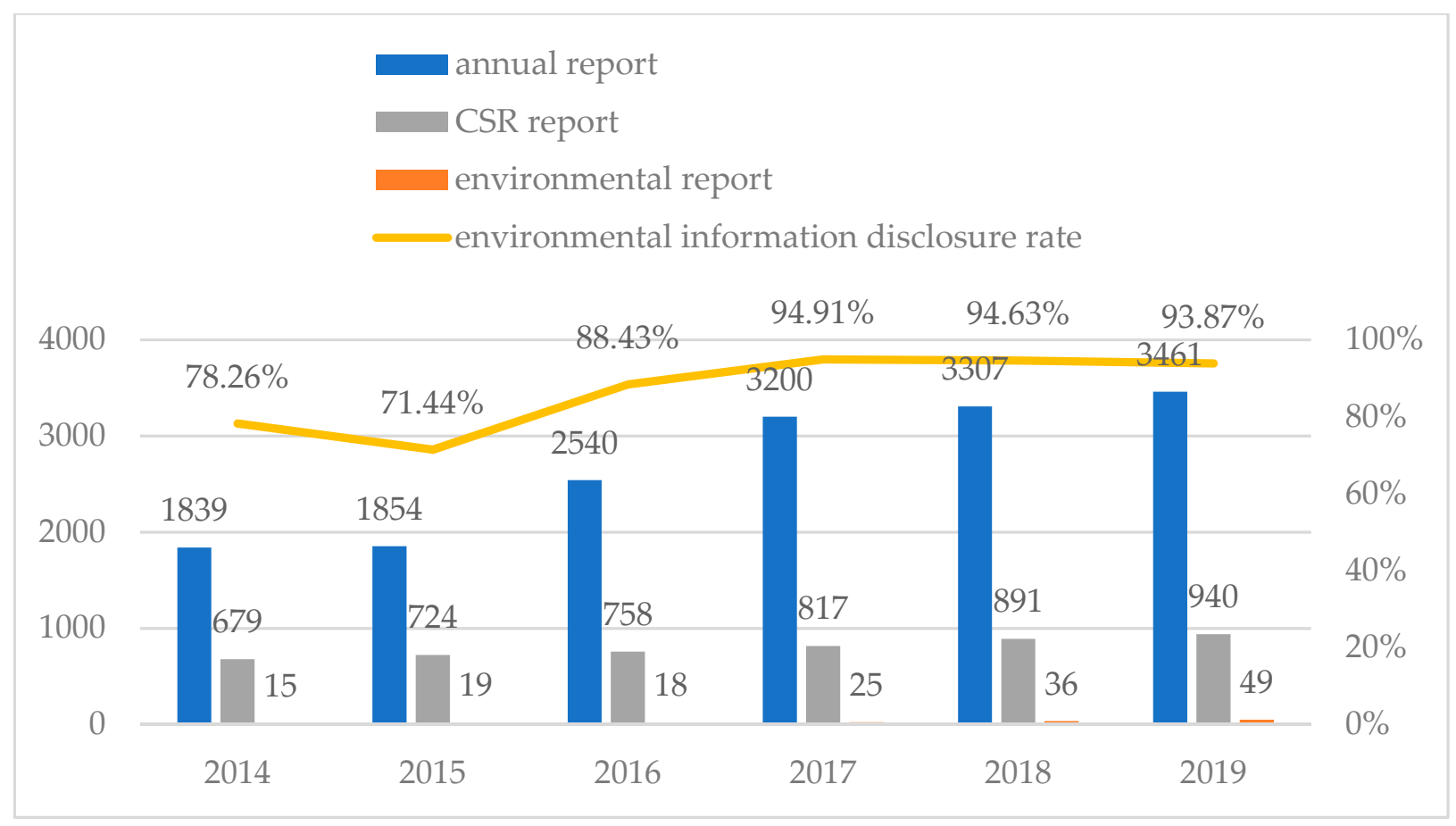

Figure 6. Statistics on the carrier and rate of environmental information disclosure of Chinese listed companies. Source: Data are from CSMAR database.

\section{Discussion and Conclusions}

Through the analysis of the disclosure status of CSR reporting of Chinese listed companies from 2008 to 2019, some strengths and weaknesses of CSR reporting of Chinese listed companies can be seen.

\subsection{The Strength of CSR Reporting of Chinese Listed Companies}

First, the number of CSR reports disclosed by Chinese listed companies has increased year by year. In particular, the number of voluntarily disclosed CSR reports has grown rapidly, surpassing the number of mandatorily disclosed CSR reports for the first time in 2017, and this trend was strengthened in the two years that followed. Based on the specific conditions of the top ten industries that disclose the most CSR reports in 2019, with the exception of the financial industry, in which most companies are listed on the mandatory disclosure list, the voluntary disclosure rates of all other industries are higher than their overall disclosure rates. This gratifying trend is influenced by the early policy of encouraging voluntary disclosure, which prompted more companies to focus on CSR and then disclose their CSR reports. To some extent, this confirms the definition of organizational legitimacy, that is, "a generalized perception that the actions of an entity are desirable, proper, or appropriate within some socially constructed system of norms, values, beliefs, and definitions" [55]. The organizational legitimacy approach offers a powerful mechanism for understanding voluntary social and environmental disclosures made by companies to address increasing political and social pressures [56]. However, it might be affected by the guidelines on the establishment of the green financial system released in 2016, which stimulate companies to engage in green projects and disclose CSR reports by providing a large number of preferential and convenient financial services.

Second, the environmental information disclosure rate has remained at a high level since 2017. Some companies publish environmental reports specifically to introduce the impact of their business activities on the environment. This phenomenon is closely related to the Chinese government's high level of attention to the environment. With the increasing development of China's economy, environmental pollution has become a serious problem. Thus, seven ministries and commissions jointly issued Guidelines for Establishing the 
Green Financial System in July 2016, requiring listed companies included in the list of key pollutant emission companies identified by the Ministry of Environmental Protection to compulsorily disclose environmental information in 2017. If the company does not disclose environmental information in 2018, it must explain why. By 2020, all listed companies must compulsorily disclose environmental information. It is the government mandatory requirement for environmental information disclosure that results in such a high rate of environmental information disclosure. This result is consistent with the findings of other authors $[57,58]$, that is, CSR disclosure plays an important role in reducing legality threats or narrowing the legality gap.

\subsection{The Weakness of CSR Reporting of Chinese Listed Companies}

However, it must be pointed out that there are still some shortcomings in CSR reporting of Chinese listed companies. First, despite the gradual increase in the number of CSR reports of Chinese listed companies, their disclosure rate has always remained within the range of 24-28\% from 2009 to 2019, and no upward trend can be seen. Although some Chinese listed companies disclose their CSR information in their annual reports, this information is often not as comprehensive and specific as the information in a separate CSR report. Therefore, it can be inferred that there are still many Chinese listed companies that have not or incompletely disclosed their CSR related information to the public. The overall disclosure status of CSR reports is not ideal, and there is still much room for improvement. In view of the conclusion of a large number of studies $[13,59,60]$ that the influence of government regulations and polices is an important institutional force to promote CSR and CSR reporting, we suggest that the Chinese government needs to (1) formulate corresponding laws and regulations to further enhance the awareness of companies to perform and disclose CSR and (2) provide incentives such as administrative approval authority, financing support, and tax incentives to attract companies to more actively participate in CSR practices and disclose CSR information.

Second, among the disclosed CSR reports, the number and percentage of verified CSR reports are low. The verification of the CSR report is a strong guarantee of its credibility [61,62]. According to the Federation of European Accountants, "CSR reporting without the authentication of the veracity of the disclosed data is rightly deemed as worth little more than advertising activities" [63]. Therefore, unverified CSR reports greatly reduce their credibility. As a result, a large number of unverified CSR reports leads to the lower overall credibility of CSR reports of Chinese listed companies. After sorting out regulations related to CSR, it can be found that there are no clear requirements for the verification of CSR reports. Therefore, in order to improve the credibility of CSR reports of Chinese listed companies, the government needs to issue relevant regulations on "the independence of the assurer, the content of the assurer's report, and the nature of what is being assured" [64] to ensure that the purpose of CSR report verification is better achieved, rather than as a symbolic practice [64].

Third, the level of information disclosure of CSR reports of Chinese listed companies is generally not high. According to the evaluation results released by RKS, despite more than ten years of development, most of the CSR reports issued by Chinese listed companies still focus on low-level disclosures, which is difficult to meet the needs of stakeholders for CSR information [18]. From a policy perspective, it is partly due to the lack of relevant standards to guide companies in preparing CR reports [65]. Therefore, if it is desired to improve the disclosure level of CSR reports, in addition to relying on the company's initiative, the government needs to issue uniform requirements for content and degree of disclosure.

In this paper, we studied the trends in CSR reporting of Chinese listed companies through statistical analysis and found that CSR reporting of Chinese listed companies has made some positive progress with the encouragement or requirement of government regulations after more than ten years of development. For example, the number of CSR reports has continued to increase, especially the number of voluntarily disclosed reports, and the rate of environmental information disclosure has increased to a high level. At 
the same time, CSR reporting of Chinese listed companies has some shortcomings that need to be improved. For example, the overall disclosure rate of CSR reports is low and shows no upward trend, the published CSR reports lack third-party certification, and the information disclosure level of most CSR reports is concentrated at a relatively low level. They are related to the lack or insufficiency of relevant government regulations. Their improvement requires the government to make more related efforts. First, the government should formulate corresponding laws and regulations to further strengthen companies' awareness of fulfilling and disclosing CSR and provide incentive policies in taxation and finance to attract more companies to actively engage in CSR and disclose CSR reports. The second is to provide necessary guidance on the content and degree of CSR information disclosures of companies of different sizes to help companies prepare high-quality CSR reports. The third is to issue relevant regulations on content, scope, and providers of verification of CSR reports to improve the credibility of CSR reports. This study has some limitations. First, in the analysis of the content of CSR reports of Chinese listed companies, we only conducted a special analysis on environmental information disclosure given its importance to Chinese current and long-term development, but it is only one of the three themes of the CSR report according to the triple bottom line. Acknowledging the fact that the content of CSR reports is extensive and there is no uniform regulation, authors of future research can specifically research the content of CSR reports of Chinese listed companies, covering all aspects of CSR reports (economic, environmental, and social aspects), as well as carrying out specific statistical analysis on the items contained in each aspect. Second, it only evaluates the credibility of CSR reports of Chinese listed companies based on whether it has been verified by a third-party organization. In fact, there are other methods to assess the credibility of CSR reports, such as quality criteria for CSR report proposed by GRI or World Business Council for Sustainable Development (WBCSD). The single evaluation method may reduce the accuracy of our judgement on the credibility of CSR reports disclosed by Chinese listed companies. Future research could employ more than one evaluation method to increase the objectivity of conclusions.

Author Contributions: Conceptualization, P.H. and X.W.; methodology, X.W.; software, X.W.; validation, X.W. and P.H.; formal analysis, X.W.; investigation, X.W.; resources, X.W.; data curation, X.W.; writing—original draft preparation, X.W.; writing—review and editing, P.H.; visualization, X.W.; supervision, P.H.; project administration, P.H.; funding acquisition, P.H. Both authors have read and agreed to the published version of the manuscript.

Funding: The research was conducted with the support of the statutory work titled "Developing the resources of the Chair of Production Engineering for conducting activities in areas related to the Priority Research Areas of the Silesian University of Technology", project number 13/030/BK_21/0065.

Data Availability Statement: Publicly available datasets were analyzed in this study. This data can be found here: [https://cn.gtadata.com/].

Conflicts of Interest: The authors declare no conflict of interest.

\section{References}

1. Jonek-Kowalska, I.; Zielinski, M. How CSR affects polish enterprises. Eur. Res. Stud. J. 2020, XXIII, 785-803. [CrossRef]

2. Cierna, H.; Sujová, E. Integrating principles of excellence and of socially responsible entrepreneurship. Manag. Syst. Prod. Eng. 2020, 28, 23-28. [CrossRef]

3. Habek, P.; Wolniak, R. Relationship between management practices and quality of CSR reports. Procedia Soc. Behav. Sci. 2016, 220, 115-123. [CrossRef]

4. Lock, I.; Seele, P. The credibility of CSR (corporate social responsibility) reports in Europe. Evidence from a quantitative content analysis in 11 countries. J. Clean. Prod. 2016, 122, 86-200. [CrossRef]

5. Tschopp, D.; Huefner, J.R. Comparing the evolution of CSR reporting to that of financial reporting. J. Bus. Ethics 2015, 127, 565-577. [CrossRef]

6. Morsing, M.; Spence, J.L. Corporate social responsibility (CSR) communication and small and medium sized enterprises: The governmentality dilemma of explicit and implicit CSR communication. Hum. Relat. 2019, 72, 1920-1947. [CrossRef]

7. Garcia-Torea, N.; Fernandez-Feijoo, B.; De, M.; Cuesta, L. CSR reporting communication: Defective reporting models or misapplication? Corp. Soc. Responsib. Environ. Manag. 2020, 27, 952-968. [CrossRef] 
8. Moravcikova, K.; Stefanikova, L'; Rypakova, M. CSR reporting as an important tool of CSR communication. Procedia Econ. Financ. 2015, 26, 332-338. [CrossRef]

9. Hąbek, P.; Wolniak, R. Analysis of approaches to CSR reporting in selected European union countries. Int. J. Econ. Res. 2013, 4, 79-95.

10. Visser, W.; Tolhurst, N. The World Guide to CSR. A Country-by-Country Analysis of Corporate Sustainability and Responsibility, 1st ed.; Greenleaf Publishing: Sheffield, UK, 2010.

11. Steurer, R. The role of governments in corporate social responsibility: Characterising public policies on CSR in Europe. Policy Sci. 2010, 43, 49-72. [CrossRef]

12. Noronha, C.; Tou, S.; Cynthia, I.M.; Guan, J.J. Corporate social responsibility reporting in China: An overview and comparison with major trends. Corp. Soc. Responsib. Environ. Manag. 2013, 20, 29-42. [CrossRef]

13. Garcia-Sanchez, I.M.; Cuadrado-Ballesteros, B.; Frias-Aceituno, V.J. Impact of the institutional macro context on the voluntary disclosure of CSR information. Long Range Plan. 2016, 49, 15-35. [CrossRef]

14. Fifka, M. The development and state of research on social and environmental reporting in global comparison. J. Betr. 2012, 62, 45-84. [CrossRef]

15. Chen, S.; Bouvain, P. Is corporate responsibility converging? A comparison of corporate responsibility reporting in the USA, UK, Australia, and Germany. J. Bus. Ethics 2009, 87, 299-317. [CrossRef]

16. Hahn, R.; Kühnen, M. Determinants of sustainability reporting: A review of results, trends, theory, and opportunities in an expanding field of research. J. Clean. Prod. 2013, 59, 5-21. [CrossRef]

17. The KPMG Survey of Sustainability Reporting 2020-KPMG Global. Available online: https://home.kpmg/xx/en/home/ insights / 2020/11/the-time-has-come-survey-of-sustainability-reporting.html (accessed on 14 June 2021).

18. Ali, W.; Frynas, G.J.; Mahmood, Z. Determinants of corporate social responsibility (CSR) disclosure in developed and developing countries: A literature review. Corp. Soc. Responsib. Environ. Manag. 2017, 24, 273-294. [CrossRef]

19. Bondi, M.; Yu, D. Textual voices in corporate reporting: A cross-cultural analysis of Chinese, Italian, and American CSR reports. Int. J. Bus. Commun. 2019, 56, 173-197. [CrossRef]

20. Yang, L.; Ngai, B.S.C.; Lu, W. Changing trends of corporate social responsibility reporting in the world-leading airlines. PLoS ONE 2020, 15, e0234258. [CrossRef] [PubMed]

21. Feng, P.; Ngai, S.C. Doing more on the corporate sustainability front: A longitudinal analysis of CSR reporting of global fashion companies. Sustainability 2020, 12, 2477. [CrossRef]

22. Russo-Spena, T.; Tregua, M.; De Chiara, A. Trends and drivers in CSR disclosure: A focus on reporting practices in the automotive industry. J. Bus. Ethics 2018, 151, 563-578. [CrossRef]

23. Weber, O. Environmental, social and governance reporting in China. Bus. Strateg. Environ. 2014, 23, 303-317. [CrossRef]

24. Li, K.; Khalili, R.N.; Cheng, W. Corporate social responsibility practices in China: Trends, context, and impact on company performance. Sustainability 2019, 11, 354. [CrossRef]

25. Carey, P.; Liu, L.; Qu, W. Voluntary corporate social responsibility reporting and financial statement auditing in China. J. Contemp. Account. Econ. 2017, 13, 244-262. [CrossRef]

26. Naveed, K.; Voinea, L.C.; Ali, Z.; Rauf, F.; Fratostiteanu, C. Board gender diversity and corporate social performance in different industry groups: Evidence from China. Sustainability 2021, 13, 3142. [CrossRef]

27. Isabel Sánchez-Hernández, M.; Gallardo-Vázquez, D.; Barcik, A.; Dziwiński, P. The effect of the internal side of social responsibility on firm competitive success in the business services industry. Sustainability 2016, 8, 179. [CrossRef]

28. Miralles-Quirós, M.M.; Miralles-Quirós, L.J.; Daza-Izquierdo, J. The assurance of sustainability reports and their impact on stock market prices. Cuad. Gest. 2021, 21, 47-60. [CrossRef]

29. Huang, T.; Wang, A. Sustainability reports in China: Content analysis. In 2010 International Conference on Future Information Technology and Management Engineering, Changzhou, China, 9 October 2010; IEEE: New York, NY, USA, 2010; Volume 2, pp. 154-158. [CrossRef]

30. Marquis, C.; Qian, C. Corporate social responsibility reporting in China: Symbol or substance? Organ. Sci. 2014, 25, 127-148. [CrossRef]

31. Parsa, S.; Dai, N.; Belal, A.; Li, T.; TANG, G. Corporate social responsibility reporting in China: Political, social and corporate influences. Account. Bus. Res. 2021, 51, 36-64. [CrossRef]

32. Ervits, I. CSR reporting by Chinese and Western MNEs: Patterns combining formal homogenization and substantive differences. Int. J. Corp. Soc. Responsib. 2021, 6. [CrossRef]

33. Qiu, J. Quality of CSR Reporting in China: A Comparative Analysis between State- and Privately-Owned Real Estate Companies. Bachlor's Thesis, University of Pennsylvania, Philadelphia, PA, USA, 2017.

34. Luo, X.R.; Wang, D.; Zhang, J. Whose call to answer: Institutional complexity and firms' csr reporting. Acad. Manag. J. 2017, 60, 321-344. [CrossRef]

35. The Reporting Exchange: An Overview of Sustainability and Corporate Reporting in China. World Business Council for Sustainable Development. 2018. Available online: http://docs.wbcsd.org/2018/02/CDSB_Case_Study_China.pdf (accessed on 13 June 2021).

36. Company Law of the People's Republic of China, Standing Committee of the National People's Congress. 2013. Available online: http://www.mofcom.gov.cn/aarticle/swfg/swfgbl/201101/20110107349089.html (accessed on 13 June 2021).

37. Shenzhen Stock Exchange Social Responsibility Instructions to Listed Companies. 2006. Available online: http:/ /www.csrc.gov. cn/pub/shenzhen/xxfw/tzzsyd/ssgs/sszl/ssgsfz/200902/t20090226_95495.htm (accessed on 13 June 2021). 
38. Guidelines for Environmental Information Disclosure of Companies Listed on the Shanghai Stock Exchange. 2008. Available online: http:/ / www.sse.com.cn/lawandrules/sserules/listing/stock/c/c_20150912_3985851.shtml (accessed on 13 June 2021).

39. Notification on Issuance of the Guideline on Fulfilling Social Responsibility by Central Enterprises. 2008. Available online: http:/ / www.sasac.gov.cn/n2588030/n2588939/c4297490/content.html (accessed on 13 June 2021).

40. Notice on Better Preparing for 2008 Annual Reports of Listed Companies. 2008 (SSE). Available online: http:/ /www.csrc.gov.cn/ pub/shenzhen/xxfw/tzzsyd/ssgs/ssxxpl/ssplfz/200902/t20090226_95559.htm (accessed on 13 June 2021).

41. Notice on Better Preparing for 2008 Annual Reports of Listed Companies. 2008 (SZSE). Available online: http:/ /www.csrc.gov. $\mathrm{cn}$ /pub/shenzhen/xxfw/tzzsyd/ssgs/ssxxpl/ssplfz/200902/t20090226_95560.htm (accessed on 13 June 2021).

42. Zhong, H.; Sun, X.; Zhang, E.; Zhang, T. China CSR Reporting Guidelines (CASS-CSR 1.0); Economic Management Press: Beijing, China, 2009.

43. Zhong, H.; Wang, J.; Zhang, E.; Lei, S. China CSR Reporting Guidelines (CASS-CSR 4.0); Economic Management Press: Beijing, China, 2017.

44. Environmental Protection Law. 2015. Available online: http://www.gov.cn/zhengce/2014-04/25/content_2666434.htm (accessed on 14 June 2021).

45. The Standards Concerning the Contents and Formats of Information Disclosure by Companies Offering Securities to the Public No.2-Contents and Formats of Annual Reports. 2016. Available online: http:/ / www.csrc.gov.cn/pub/zjhpublic/G00306201/20 1612/P020161216527602709328.pdf (accessed on 14 June 2021).

46. Guidelines for Establishing the Green Financial System. 2016. Available online: http://www.scio.gov.cn/32344/32345/35889/36 819/xgzc36825/Document/1555348/1555348.htm (accessed on 14 June 2021).

47. Provisions on the Management of the List of Organizations Discharging Key Pollutants. 2017. Available online: https://www. mee.gov.cn/gkml/hbb/bgt/201712/W020171201468746002498.pdf (accessed on 14 June 2021).

48. Code of Corporate Governance for Listed Companies. Beijing, China. 2018. Available online: http:/ /www.gov.cn/gongbao/ content/2019/content_5363087.htm (accessed on 14 June 2021).

49. Petkoski, D.; Twose, N. Public policy for corporate social responsibility. In Proceedings of the WBI Series on Corporate Responsibility Accountability, and Sustainability Competitiveness (E-conference), Washington, DC, USA, 17-25 July 2003; Available online: http:/ /info.worldbank.org/etools/docs/library/57434/publicpolicy_econference.pdf (accessed on 14 June 2021).

50. China Security Market and Accounting Research (CSMAR). Available online: https:/ / cn.gtadata.com/ (accessed on 14 June 2021).

51. Rankins CSR Ratings. Available online: http:/ / www.rksratings.cn/ (accessed on 14 June 2021).

52. Zhong, M.; Xu, R.; Liao, X.; Zhang, S. Do CSR ratings converge in China? A comparison between RKS and Hexun scores. Sustainability 2019, 11, 3921. [CrossRef]

53. Liu, K.; Lin, B. Research on influencing factors of environmental pollution in China: A spatial econometric analysis. J. Clean. Prod. 2019, 206, 356-364. [CrossRef]

54. Hao, Y.; Zheng, S.; Zhao, M.; Wu, H.; Guo, Y.; Li, Y. Reexamining the relationships among urbanization, industrial structure, and environmental pollution in China-New evidence using the dynamic threshold panel model. Energy Rep. 2020, 6, 28-39. [CrossRef]

55. Suchman, M.C. Approaches and Strategic Managing Legitimacy. Acad. Manag. Rev. 1995, 20, 571-610. [CrossRef]

56. Gray, R.; Owen, D.; Adams, C.A. Accounting \& Accountability: Changes and Challenges in Corporate Social and Environmental Reporting; Prentice-Hall: London, UK, 1996.

57. Nikolaeva, R.; Bicho, M. The role of institutional and reputational factors in the voluntary adoption of corporate social responsibility reporting standards. J. Acad. Mark. Sci. 2011, 39, 136-157. [CrossRef]

58. Cho, C.H.; Patten, M.D. The role of environmental disclosures as tools of legitimacy: A research note. Account. Organ. Soc. 2007, 32, 639-647. [CrossRef]

59. Cambell, L.J. Why would corporations behave in socially responsible ways? An institutional theory of corporate social responsibility. Acad. Manag. Rev. 2007, 32, 946-967. [CrossRef]

60. Aaronson, S.A.; Reeves, J. The European Response to Public Demands for Global Corporate Responsibility; National Policy Association: Washington, DC, USA, 2002.

61. Gürtürk, A.; Hahn, R. An empirical assessment of assurance statements in sustainability reports: Smoke screens or enlightening information? J. Clean. Prod. 2016, 136, 30-41. [CrossRef]

62. Kolk, A. Sustainability, Accountability and corporate governance: Exploring multinationals' reporting practices. Bus. Strateg. Environ. 2008, 17, 1-15. [CrossRef]

63. Habek, P. Corporate Social Responsibility Reporting. Practices of Visegrad Group Countries; PA NOVA SA: Gliwice, Poland, 2017.

64. Michelon, G.; Pilonato, S.; Ricceri, F. CSR reporting practices and the quality of disclosure: An empirical analysis. Crit. Perspect. Account. 2015, 33, 59-78. [CrossRef]

65. Utama, S. An evaluation of support infrastructures for corporate responsibility reporting in Indonesia. Asian Bus. Manag. 2011, 10, 405-424. [CrossRef] 